faults hading westwards at angles up to about $20^{\circ}$ and branching off from the normal faults.

Taken together, all the evidence shows that the faulting was initiated during the latest phase of the cooling and consolidation of the granite, and that it is most likely due to uplift of the granite. It is interesting to recall that Collins (1902, p. 712) remarked on the "trough-like drop of the ground between the granite masses" and showed this in a diagrammatic section.

It is clear that the final phase in the deformation history of South-West England was one of extensive faulting, resulting in the rocks being cut up into a number of small blocks. What is particularly interesting in the Bodmin Moor-Dartmoor region is the dominance of the north-west-south-east faults and the apparent general absence of north-east-south-west faults, although in the Tintagel area, according to Wilson (1951, p. 420), the late normal faults have this latter trend.

\title{
REFERENCES
}

Blyth, F. G. H., 1957. The Lustleigh fault in North-East Dartmoor. Geol. Mag., xciv, 291-6.

Collins, J. H., 1902. Notes on the principal lead-bearing lodes of the West of England. Trans. Roy. Soc. Geol. Cornwall, xii, 683-718.

Wilson, G., 1950. The tectonics of the Tintagel area, North Cornwall. Quart. Journ. Geol. Soc., cvi, 393-432.

N. E. Butcher.

Geology Department,

THE UNIVERSITY,

READING.

12th September, 1957.

\section{DETERMINATION OF [001] AXES IN MUSCOVITE.}

Owing to an unfortunate oversight there is a printing error in the letter under this heading published in the last number of the Geological Magazine. From line 13 to line 70 all references to [001] should read (001).

In line 76, [001] should be followed by the word " axes".

\section{PUBLICATIONS RECEIVED}

F. J. NORTH. Sunken Cities. pp. 256, with 17 text-figs. and 13 plates. University of Wales Press, Cardiff, 1957. Price $18 s$.

N. L. Bowen. The Evolution of the Igneous Rocks. pp. $332+82$ text-figs. Dover Publications, Inc., New York, 1956 (Vision Press, Ltd., London). Price: cloth 30 s., paper $15 s$.

W. M. Davis. Geographical Essays. pp. $777+130$ text-figs. Dover Publications Inc., New York, 1954 (Vision Press, Ltd., London). Price 24s.

B. GUTENBERG (Edit.). Internal Constitution of the Earth. pp. $439+43$ text-figs. Dover Publications, Inc., New York, 1951 (Vision Press, Ltd., London). Price 20s.

G. A. EIBY. Earthquakes. pp. 168 with 54 text-figs. and 32 pls. Frederick Muller, Ltd., London, 1957. Price 21s.

R. D. NinINGer (Edit.). Exploration for Nuclear Raw Materials. pp. xv + 293 with numerous text-figs. Macmillan and Co., Ltd., London, 1957. Price 55s. 